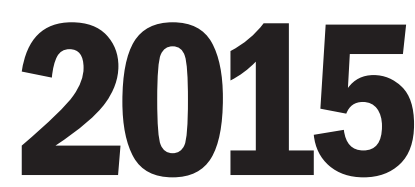

volume 12 | issue 1 an open access journal for architectural research

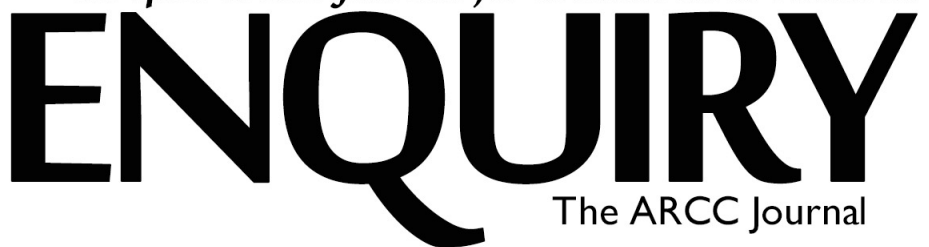

\title{
The Architect as a Social Designer: The Fun Palace Case
}

\author{
Lubomir Popov \\ Gary David
}

\begin{abstract}
The goal of this paper is to discuss how the architectural profession and its work, through development of physical structures, relate to the idea of social design. Toward this end, we explore a number of issues that emerge from this concept-the social role of the architect, the emerging engagements in social design, and the need for corresponding design ethics. Through an applied sociological approach that focuses on interaction, emphasizing collaborative and transformative work within situated contexts, we conduct a case study on a project known as The Fun Palace. Rather than providing a detailed examination of the Fun Palace or its architect, Cedric Price, this paper uses this case to explore and discuss the potential for architecture in social design. Consequently, the study contributes to the ongoing debate on the social role of the architect, the scope of the architectural profession, and involvement with social design.
\end{abstract}

Keywords: Architecture-Professional Aspects, Sociology of the Profession; Social Design; Facilities Planning and Programming

\section{INTRODUCTION}

Professions, and the professionals who occupy them, are made of more than just the possession of a particular technical knowledge that sets them apart from those in other professions. Of additional consideration

\section{Permissions and copyright}

Authors retain copyright and grant the journal right of first publication with the work simultaneously licensed under a Creative Commons Attribution License that allows others to share the work with an acknowledgement of the work's authorship and initial publication in this journal (Attribution-ShareAlike).

\section{Creative Commons Attribution 3.0 Unported (CC BY 3.0)}

You are free to: Share - copy and redistribute the material in any medium or format. Adapt — remix, transform, and build upon the material for any purpose, even commercially. The licensor cannot revoke these freedoms as long as you follow the license terms.

Under the following terms: Attribution - You must give appropriate credit, provide a link to the license, and indicate if changes were made. You may do so in any reasonable manner, but not in any way that suggests the licensor endorses you or your use.

No additional restrictions - You may not apply legal terms or technological measures that legally restrict others from doing anything the license permits.

How to cite:

Popov, Lubomir and Gary David. 2015. "The Architect as a Social Designer: The Fun Palace Case." Enquiry 12 (1): 9-16. http://dx.doi.org/10.17831/enq:arcc.v12i1.388 is the manner in which those who are engaged in that profession conceptualize their work, and the manner in which it is carried out. Thus, the trajectory of any profession can be traced through its history of emergence, establishment, and evolution (Burrage and Tornstendahl 1990; Dingwall 2008; Dingwall and Lewis 1983; Macdonald 1995). The evolution of a professional is a major mechanism for sustaining the livelihood of professional members and communities, as it reacts and responds to the changing nature of demands and context. Every profession faces challenges and choices as a result of social and technological developments, evolution of the clients and their needs, and emergence of new types of providers who aggressively fight for a piece of the market (Burrage and Tornstendahl 1990; Dingwall 2008; Dingwall and Lewis 1983; Macdonald 1995). Included in this is a long process of adjusting clients' needs and expectations and providers' scope of services, evolution of social problems and the need for new solutions, and the internal logic of the profession itself.

The architectural profession has experienced evolutionary pressures as well, being called on to respond to new social situations and technological changes (Cuff and Wriedt 2010; Duffy and Hutton 1998; Kostof 1977; Woods 1999). We can trace this progression from ancient Greece to the master builders of medieval cathedrals and edifices, to the specialization and division of labor that proliferated during the Industrial Revolution, to the challenges of the second half of the 20th century and the emergence of the new economies-post-industrial, service, information, experience, and so forth (Crinson and Lubbock 1994; Kostof 1977). Through these historical processes, the architectural profession has defined and redefined itself depending on the social circumstances, its social status, and the ideologies that shape the mind and consciousness of its individual members (Crinson and Lubbock 1994; Kostof 1977). Architects have usually responded quickly to economic and technological changes, social developments, and new intellectual movements. The profession has come a long way from serving the aristocracy and clergy to helping ordinary people, civic associations, and communities (Crinson and Lubbock 1994; Stevens 1998). Architects have been involved in social movements, adopted ideologies of equality and social justice, and started translating these views in building programs and design projects. The profession has transcended the closed world of the rich and has started working for ordinary people, consulting both 
community leaders and individual users. In this process, architects have taken over new roles, providing not only consultations about the built environment, but also about social organization, politics of justice, and new forms of work cooperation and collaboration (Nicol and Pilling 2000; Piotrowski and Robinson 2001).

New social pressures and demands are emerging that are driving architects to position themselves as experts who design spaces that encourage particular kinds of activity to take place, such as increased collaboration. Collaborative spaces can be designed to encourage colleagues to work together more frequently, such as with open offices. Work environments, and training programs, can be designed to facilitate greater mutual monitoring and achieve greater knowledgesharing among co-workers (Whalen and Vinkhuyzen 2001; Whalen and Whalen 2011). Additionally, the architect can inhabit the position of a consultant who tells a client what is needed, translating the client's brief into spaces, spatial configurations, and additional support (Callon 1986; Latour 1987). In these ways, the architects' role has the potential to be far more than simply transforming the client's requests into a design. They are being called on to produce structures that are not an end in and of themselves, but a necessary condition through which a particular social end can be achieved.

To examine these developments, we explore the extent to which architects expand their service offerings and engage in new aspects of design. In doing so, we contribute to a new perspective on the architectural profession through engagement with activities tantamount to social design. Accordingly, this paper is organized into three major parts. First, we introduce the theoretical and methodological foundations of our approach. This is broadly rooted in the social sciences, and more specifically in applied sociology, workplace studies, and symbolic interactionism. Second, we present an analysis of the Fun Palace case, highlighting the social design component and providing information about the social context, the client, the maverick designer, and the design of a new social organization. The third part presents the implications of the Fun Palace as a precedent for re-envisioning the scope of the architectural profession through a discussion of the social design component of the project delivery process and its impact on the architectural profession, the expanding roles and responsibilities of the architects, and subsequent ethical obligations.

\section{THEORETICAL AND METHODOLOGICAL CONSIDERATIONS}

This study contributes to re-envisioning the scope of the architectural profession, particularly its social interventions and responsibilities that emerge from this. These issues have acquired particular importance with rapid sociocultural change in our times. The massive cultural, economic, and social shifts currently taking place call for re-examination of all aspects of everyday life. Likewise, this creates new opportunities for professional engagement in this rapidly changing environment. The architectural profession is foundational in this, in the figurative and literature sense. In terms of people's work, we are witnessing the emergence of new tasks and challenges, the interdisciplinary crossing of professional boundaries and the proliferation of new specialties. This is all occurring in a workplace that is simultaneously more collaborative while being more globally dispersed and multi-culturally diverse.
Massive technological changes are permeating all areas of social life, causing reconsideration of what is and what should be possible. In this milieu, we examine the role of the architect in social design.

Other industries concerned with design increasingly have been turning to the social realm for inspiration of what can be achieved, and better understanding of what currently is being done in situated contexts. In user experience, for example, a shift has occurred in which ethnography of work is viewed as a necessary part of the product lifecycle. Software and hardware design likewise is exploring how work occurs in context, identifying opportunities and understanding how technologies are currently used. In service design, recommendations are being made for use of video to create opportunities for a better customer experience (Buur, Binder and Brandt 2000).

The social turn in engineering and design can be traced to the work of Harold Garfinkel (1967) and his focus on the study of in-situ practices as the locus of meaning during social interaction. Studies of work, whether at an actual workplace or the 'work' of doing everyday interactions, became applied in various institutional contexts. The area known as workplace studies became used in industry as social scientists (primarily sociologists and anthropologist) focused their knowledge of social processes and observational skills on how to design products through a locally embedded understanding of workplace activity (see Luff, Hindmarsh and Heath 2000; Rawls 2008).

This paper is also rooted in symbolic interactionism as a theoretical approach (Blumer 1969; Denzin 2001). Based on the idea of interaction with and reaction to a given event or object, we adopt this as how meaning is achieved through engagement not only with others, but with the environment around which those interactions occur. Symbolic interaction takes that meaning that occurs through interactions with others, and things become meaningful for them out of those interactions. Typically, this is in reference to an interlocutor who is a person, but can also refer to engagement with space. As noted by Smith and Bugni (2006), much symbolic interaction has been concerned with the physical environment. It is not only the ability of architecture to connect with the individual self, but also to help construct interactions with other selves.

By social design influencing behavior, we do not mean that a design strictly determines a specific behavior. However, it does mean that the range of preferred behaviors can be constructed through such design. This recalls more of a conversation analytical and ethnomethodological stance toward design. For example, conversation analysis examines how meaning is achieved through the sequential production of talk, in which any utterance becomes meaningful in the context of the conversation and situated context. While one turn of talk does not limit what another person can say, it does limit what kind of utterance would be seen as relevant within that interaction. Asking a person "How are you?" does not dictate precisely what will be said next, but it does determine what kind of response will be viewed as relevant to that question (Sacks, Schegloff, and Jefferson 1974). In other words, a physical design might not dictate precisely what people do within that space, but design can encourage a range of behaviors through creation of social expectations based on situational preferences. 
Additionally, symbolic interactionism recommends working with informative cases rather than representative samples of target populations. When researching novel and emerging phenomena, it is productive to use extreme case analysis since these are cases that carry the seeds of ideas with the possibility of a future flourishing and becoming customary practices (Eisenhardt and Graebner 2007; Flyvbjerg 2006; Seawright and Gerring 2008).

To explore the potential for architecture as social design, we reviewed a number of cases that are potential candidates due to their nature and vision. Arcosanti by Paulo Soleri is a great project in this respect, as is the George Pompidou Center by Renzo Piano. Analyzing the social thinking of modernists would be very productive, as well as looking at examples from recent practices in functional facility programming for hospital design.

However, the Fun Palace by British architect Cedric Price was selected due to the extensive social deliberations involved in its development, and the extraordinary social solution it provided (Mathews 2007a; Nadine 2011). Selection of the Fun Palace case is also an attempt to raise awareness that such practices have not become conventional, and that we need to be more persistent in fostering the social design component in architectural practice. It is important to emphasize that this paper is not about the Fun Palace or Cedric Price, per se. Rather, the case is used as a methodological tool to discuss the social design aspect in architectural work. The Fun Palace endeavor offers a glimpse into the future and provides rich material for current discussion about the scope of architects' engagement in social design.

Considering the goals and objectives of this publication, social design is conceptualized as an activity for introducing order into future social situations. It has "as its primary consequence the specification of a range of alternatives for channeling social behavior" (Boguslaw, 1971). Boguslaw (1971) calls "social designers" all people who engage in such activities, whether they think of themselves in these terms, though "many, probably most of them, are not social scientists." He is convinced that social design is implicit in contemporary social decision-making.

Design is an activity that generates new morphological representations that will be used as guides in the process of implementation. Social design is about organizing social morphology in a new way to achieve particular goals. Social morphology refers to the structure and "material" of social entities, processes, and other phenomena. Social design develops new solutions to social problems, proposes models for social change, and produces blueprints for achieving social objectives. Blueprints present a desired and possible future state of social organisms, processes, and behavior systems. This is accomplished by developing new connections, relations, and interactions between components and subsystems.

\section{THE FUN PALACE PROJECT: DESIGNING A NON-BUILDING The Project Context: Radical Situation, Dissident Thinkers}

The Fun Palace has been called an "experiment in architecture and technology" that was meant to address the social, economic, and technological transformations taking place during that time (Mathews
2005). Thus, to understand the Fun Palace project, one must consider the social situation in Great Britain during the late 1950s and early 1960s. The country was experiencing the collapse of the Empire, declining international status, economic restructuring, and very high unemployment (Gamble 1994; Glynn and Booth 1996; Holdsworth 2011; Mathews 2007a). The population (particularly the working class) was disillusioned, frustrated, and apathetic. A number of intellectuals were predicting that emerging automation and robotics in industry would decrease the length of the workweek while unemployment would continue to grow (Gamble 1994; Glynn and Booth 1996). There was also concern that unemployment would lead to moral degradation resulting from debilitating lifestyles among the unemployed. This led to suggestions that working class people could be saved by engaging them in social activities and teaching them new professional skills (Gamble 1994; Holdsworth 2011; Mathews 2007a).

The Fun Palace started as an innovative theater project initiated by the famous avant-garde theater director Joan Littlewood (Holdsworth 2011; Littlewood 2003; Mathews 2007a, 2007b) at the beginning of the 1960s. Littlewood conceived a new type of theater in response to the major social problems of her time (Holdsworth 2011; Littlewood 2003). Infatuated with German director Bertolt Brechtian's ideas of audience engagement, street theater, and theater for the masses, Littlewood is known for her experimental and political theater concepts, search for new theater directing methodologies, and new relationships among theater, audience, and society (Holdsworth 2006). She sought to use theater as an instrument for raising the social consciousness of the working class people to release them from the grip of passivity and apathy, educate them, motivate them, and make them active participants in social life.

Littlewood's theater consistently broke the fourth wall between the audience and actors, and even encouraged spectators to join the actors on stage. She envisaged performance spaces to provide opportunities for the audience to collaborate and co-create with the actors, presupposing a spatial organization completely different from existing theater houses (Holdsworth 2011; Littlewood 2003). Since existing buildings could not satisfy her radical requirements and remodeling would not have helped to accommodate Littlewood's theater needs, a new facility was in order-something different, something without a precedent, with extended social functions. By chance, she met a young architect, Cedric Price, and shared her plans with him (Mathews 2007b).

\section{The Maverick Designer}

Littlewood's ideas about using theater as a vehicle to educate and motivate working class people impressed Cedric Price. He had mulled over the plight of the working class himself during times of rapid economic restructuring. He had witnessed his own father being forced to change careers (Mathews 2003, 2007a). Price reflected on the educational system in the context of having been homeschooled, his encounters with outdated university practices, and his dissatisfaction with the institutional learning environments that promulgated inequality and inefficient knowledge acquisition (Mathews 2007a).

Price was not only an architect but a thinker interested in many of the problems with which Littlewood grappled. He was notorious for his daily 
banter with prominent British intellectuals, scholars, and politicians on myriad topics, including public education, new forms of learning, and new organizational structures. His interest in the educational system was inextricably linked to issues of democracy, empowerment of the masses, citizen participation, continuing education for adults, new forms of leisure and entertainment, and emerging electronics and computer technologies (Mathews 2007a, 2007b). Price dealt with the concept of an all-pervasive play that would foster personal growth and civil awareness of the masses. He delved deeply into social issues. Fueled by a humanitarian impulse and philosophical acumen, he frequently explored these topics with the political and intellectual elite. Such discussions and investigations constituted the foundation for his social design work, where he employed his talents and interests to explore and develop ideas in an informal way (Mathews 2007a, 2007b).

\section{Reformulating the Project and Organizing the Process}

After some deliberation with Littlewood and reflection on his own vision, informed by his beliefs about the social situation in Britain, Price was fascinated with Littlewood's idea and started working on it pro bono, leaving other small commissions aside (Mathews 2007a). However, he soon started envisioning the project unfolding in a new way. Consequently, he took leadership of the project, going far beyond typical architectural routines in his revision (Mathews 2007a). This shifted the client/consultant arrangement in a fundamentally important way as he began to define how to envision the project.

Architects thrive on reformulating problems, and are thus famous for questioning a client's vision regarding their project. This can include offering additional functions, technological features, and new aesthetic directions that were not included in the client's initial stated needs. Architects typically start seeing new dimensions, aspects, and priorities, with which they formulate a new problem to work on. It was in this manner that Price redefined Littlewood's theater brief (Mathews 2007a) and came up with the idea of a novel type of institution for informal adult learning and entertaining where people could freely engage in intellectual activities in a fun and relaxing atmosphere.

Although Littlewood initiated the facility development process, Price began coordinating the entire project after redefining the problem (Iles 2009; Mathews 2007a). He volunteered for responsibilities far beyond the scope of the typical architect during the conception of a new building; he served as planner, manager, and entrepreneur (Iles 2009; Lobsinger 2000b). Beyond the project demonstrating his engineering approach to finding solutions, it also reflected his engagement with the design of a new social institution and organization.

Price began developing detailed ideas for educating the working class in an interactive play environment (Price 1964; Price and Littlewood 1968), including activity systems and the manner in which activities would be conducted. To manage this huge volume of work on a pro bono basis, he created several committees with experts to work on the social component of the project while continuing to play important roles. He was, for example, very active on the Cybernetics Committee chaired by Gordon Pask, which actually engaged in social design. Pask, a famous cybernetician (Frazer 2001; Lopes 2009), acknowledged Price's leading role as a social designer, and on a number of occasions encouraged Price to think of himself as a social engineer (Frazer 2001; Lobsinger 2000a, 2000b; Mathews 2007a, 75).

\section{Designing a New Social Organization}

Price's vision transcended Littlewood's original idea of engaging and assisting the working class through theater (Price 1964; Price and Littlewood 1968) by placing emphasis on professional refurbishing and continuing education for the unemployed. Furthermore, he imagined how this could be accomplished in a pleasurable social environment with the capacity to unleash limitless intellectual potential and make learning exciting and fun. Ultimately, he was engaged in constructing a new way of learning emerging from play, entertainment, and leisure (Iles 2009; Wilken 2007; Shubert 2004, 17). Although Littlewood had started with similar ideas, in architectural terms, her innovation was limited by the theater building type (Littlewood 2003). Conversely, Price saw far vaster opportunities and proposed something considerably broader (Allford 1984, 7; Wilken 2007). Price outlined his novel concept for a combined institution and organization that included functions of several customary institutions and brought together elements of several social organizations. This constituted a considerable innovation for the time as well as an obvious act of social intervention by design. Price looked beyond delivery of a design based on his client's stated aim, but rather extended and translated those aims to achieve social transformation through design.

Price was fascinated with the opportunity to work on new forms of human development and the "production of the social and the individual" (Lobsinger, 2000b, 128), and pioneered the concept of education through fun and what we call "edutainment" today (Shubert 2004, 17). Price was heavily involved in exploring how workers' free time could be used not only for leisure and entertainment, but also for personal development and growth, intellectual training, and acquiring new skills for the new restructured economy (Holdsworth 2011; Mathews 2007a). He was engaged with issues of active learning, participatory education, self-education, de-institutionalization of education, personalization of educational activities, opposition to tabloid culture and brainwashing, trivialization of everyday life, conformity, anaesthetization, mass debilitation, increased civic involvement, generating sociality, liberation and emancipation, and participatory democracy (Holdsworth 2011; Lobsinger 2000a, 2000b; Mathews 2007a).

After researching and analyzing relevant social issues, developing goals and objectives, and envisaging in general terms the nature of the new facility, Cedric Price engaged in designing activity systems (Price 1964, 1984). He envisioned myriad user activities, how they would take place, and possible behavior patterns that would emerge. The project committees generated long lists of potential activities (Lobsinger 2000a, 2000b; Mathews 2007a) in considerable detail that were largely doomed to remain theoretical in nature as they attempted to anticipate how people would learn in the Fun Palace environment using various kinds of electronic equipment and what educational benefits they might attain (Mathews 2007a).

In this phase of the project, Cedric Price had a major role in 
conceptualizing this new social entity with respect to the social problems that it had to resolve, its major social functions, its mission, and the goals and objectives it had to support. Additionally, he developed a number of important social considerations and envisioned several concerns that defined the nature of the social organism and led to the sketching of a social institution of a completely new type. It was very different from previously known institutions, and even different from the mechanical assembly of selected components of existing institutions into a new whole. This kind of work is similar to strategic planning, and constitutes a significant contribution to the still undefined field of social design. It is also a close precursor of what we now call service design, in which all aspects of the service encounter are considered in relation to how a 'user' encounters them to improve experience.

Unfortunately, after this phase, the Fun Palace project was cancelled (Mathews 2007a). A building permit was never issued because the local community opposed the project on the grounds of it potentially having a negative social impact on the surrounding neighborhoods (Mathews 2007a). However, Price's accomplishments at this phase remain an example of innovative social design thinking, and serve as a benchmark in civic building design that is exceptional even by today's standards. Development of the Fun Palace influenced several of Cedric Price's future projects, and the famous Centre Georges Pompidou (Beaubourg) in Paris (Silver 1994).

\section{IMPLICATIONS FOR THE ARCHITECTURAL PROFESSION}

Cedric Price boldly questioned the scope of the architectural profession by expanding it beyond the physical structure and into the realm of the social encounters and engagement that occurred therein. Price challenged the social scientists and thinkers on his project committees to engage in social design, and bring social science expertise into the organization of human environments. His projects highlighted an area that is not covered by traditional architectural expertise. In the absence of social designers, Price took over that responsibility and confidently organized the process of creating the Fun Palace, outlining a new professional approach and new perspective on the scope of architectural engagements in their projects.

This section discusses three interrelated issues: social design in the project delivery process and implications for the architectural profession, rethinking the role and responsibilities of architect, and emerging ethical obligations.

\section{Social Design in the Project Delivery Process and Implications for the Architectural Profession}

Littlewood's initial idea for her project informs about social practices, visions, and expectations regarding facility development at that time (Mathews, 2007a). Even today, clients often do not have an adequate social and functional definition of their projects and could ask for the wrong building, like proactive patients asking their physicians for the wrong medication. Clients typically are not aware of the social underpinnings of their building project and more generally their worksites. Those who understand these underpinnings, such as clinical and applied sociologists, industrial anthropologists, or other workplace ethnographers, typically are not consulted to assist them in clarifying their intentions before deciding that a new building is needed. Clients are rarely aware that their social organization (in sociological terms) is at the center of their facility project, not the building itself. When they experience a problem with inadequate facilities, clients do not feel a need for a social designer, organizational designer, or management consultant; they think about finding an architect.

Thus, architects are approached by clients without a preliminary understanding of the social context and nature of the project. People perceive buildings as material artifacts only; they experience their materiality and are not attentive to their social functional aspects. Consequently, clients are not aware of their own role in the building delivery process, and they want to delegate their responsibility to the professionals they believe should know everything about buildings. While this may be true, what is less understood by architects is what needs to be known about the social environment, something for which they receive little training. This results in an integral missing link in the building delivery process.

The Fun Palace case and scope of Cedric Price's involvement demonstrate that the design of the social organization is the foundation for formulating problems of spatial organization, structures, and equipment. In terms of the Fun Palace design, a traditional architect likely would have redefined Littlewood's brief, but most probably would have kept close to the idea of a theater with an open stage and audience seating that enhances viewer interaction and participation. What Price recognized is that most of the project work in the initial stages is about organizational design.

Considering the implications of this for the architectural profession, there are several options to consider. One option is the "anti-architect" like Cedric Price (Mathews 2007b; Price 2003; Wigley 2004; Wilken 2007). The "anti-architect" is still an architect, but is one who engages in social design. Such a person is trained as an architect and possibly has expanded his/her professional horizons through explorations of the humanities, social sciences, and organization design.

Another option is the professional social designer. Currently, there is no such official occupation specifically for this purpose (though other disciplines can contribute to this effort). There is, in fact, strong opposition to social design coming from all sides of the political spectrum, and it will take a lot of time to develop and institutionalize such a profession. In the Fun Palace project, the professionals most closely involved in social design were architect Cedric Price and prominent cybernetician and psychologist Gordon Pask. It is interesting that the architect managed to keep a balanced, humanistic approach to building users, their needs, and activities. However, the psychologist demonstrated a certain dose of excess with his desire to track unconditionally human behavior and predict in what activities people would like to engage. In some way, this should not astonish us, considering the predominant positivist and behaviorist thinking in the social sciences at that time.

A third alternative is the professional facilities programmer with major engagements in organizational design and functional programming. Current programming practices in healthcare and correctional facilities indicate the existence of such professionals in small facilities planning operations or the strategic design units of the largest architecture 
firms. This option implies a specialized architectural position and job responsibilities, supported by extensive education in the social sciences. It is different from the anti-architect exemplified by Cedric Price. Programmers usually have design engagements and very extensive social science training. Analyzing the scope of expertise involved in the conceptualization of the Fun Palace, the ensuing professional biases and drifts, and the status of programming, it is prudent to think about the future of programming as a job position and profession with its own identity.

A fourth option is to have this diverse expertise delivered by an interdisciplinary team. This practice is used most often by facilities planning firms. There, experts come from several professions. They gradually develop knowledge and skills in a team environment where they work on facility programming and planning projects. In some way, the Fun Palace project is one of the precursors of modern planning and programming teams and firms. However, even by modern standards, the diversity of expertise and professional affiliation, the number of committees, and the complexity of the work organization are quite astonishing.

\section{Rethinking the Architectural Profession: New Roles and Responsibilities}

With this project, and particularly with its social design components, Cedric Price charted a new domain of architectural project responsibilities. As an architect, he conceptualized his work as anti-architecture and nonbuildings, and he was proud of that (Mathews 2007a, 2007b; Price 2003; Wigley 2004; Wilken 2007). While this wording might be a bit clumsy, it communicated his dissatisfaction with the architectural practices of the time and conveyed his vision for an expanded role of the architect. Price wanted to see architects organize everything-even social processes and institutions-and ultimately have them initiate social design interventions of various kinds at several levels of the societal system.

Price even came to the idea that the best solution to the client's problem was not a building, but rather a social design. He envisioned restructuring the client's organization, introducing changes in society and social situations, and resolving sociospatial problems with social action rather than new buildings (Mathews 2007b). From this point of view, he treated buildings like prosthetics for social processes and activities, desiring to see building structures as transient and ephemeral as the social processes, which is why he planned the materiality of Fun Palace and a few other projects to last as long as their respective social organizations were needed (Mathews 2007a).

Cedric Price boldly entered social design, a new field, and courageously charted new projects for education, human development, cultural intervention, leisure and recreation, user choice, and cybernetic selforganization of social entities and facilities. In addition, he offered ideas very similar to "edutainment" (Shubert 2004, 17), self-paced learning, adult and continuing education, reality television, cybercafés, and electronic technology 40 to 50 years ahead of his time. In practice, Cedric Price enthusiastically engaged in designing a new kind of social institution and its corresponding social organization. Such involvement in social design needs to be considered very carefully and with special attention to social responsibilities, power, ethics, and interaction with clients and other allied professions.

\section{From New Professional Roles to New Ethical Obligations}

Although Price started the project with altruism and good intentions, some things took a strange turn and began to threaten basic human liberties and wellbeing in the process of developing initial plans for the Fun Palace. The intent to control user behavior throughout the whole facility can be quite disturbing, for example. With the progress of the user activities planning, the cybernetic committee started designing tools for collecting information about user needs and preferences, and building utilization data, resulting in the project developing a strong social control stance. Even Cedric Price barely expressed concerns about the issue of surveillance and social control (Holdsworth 2011; Lobsinger 2000; Mathews 2007; Wilken 2007), and Joan Littlewood needed a lot of time to realize its potentially dangerous implications.

Another example is the planning of art therapy and psychodrama activities to be freely accessible to all participants in the Fun Palace events. The social designers obviously did not consider the requirement for accreditation of such activities and the need for employment of licensed professionals. Holdsworth (2011, 215-216) warns that if such proposals are not developed according to professional requirements, there might be severe unexpected side effects for patrons in terms of their mental health and overall wellbeing. These examples, however, are simply illustrative of the complexity of social design and the necessity to engage in it professionally.

The Fun Palace case demonstrates many decisions that might have substantial influence on people's wellbeing, health, treatment, and liberties. It is obvious that facilities planning processes are heavily loaded with important decisions regarding individuals and social groups. Such decision-making is often tantamount to social design. The examples with cybernetic control and psychodrama activities raise a red flag and ask for exceptional attention and consideration when engaging in social design types of activities. At stake are important human values and freedoms. The people empowered to make such decisions should be highly competent and ethical. This raises the issue that professionals engaged in social design activities should take a "do no harm" oath. This would not be something new, considering the Hippocratic Oath of medical doctors, who pledge they will always keep in high regard the interests and welfare of their patients.

\section{CONCLUDING REMARKS}

The paper is intended for architectural theorists and thinkers who want to re-envision the scope of the profession, specifically the architect's engagement in social design. Cedric Price's vision of the Fun Palace is used to magnify the volume of social design work involved in developing untraditional and unique civic facilities. In this case, the architect, Price, daringly engaged in activities that in their entirety are tantamount to social design. He was encouraged to function as a social designer by his client, Joan Littlewood, and other prominent project participants such as Gordon Pask. His inclination to discuss social issues, develop personal opinions regarding important societal phenomena, and envision 
solutions to major social problems facilitated his engagement with the Fun Palace project. Besides, Price had propensity for re-envisioning and inventing things from new architectural structures and construction systems to equipment and technology. Most important for this study, however, was Price's insight concerning the ways people learn, celebrate, and enjoy life. His work and legacy clearly demonstrate the scope and breadth of architectural intervention in designing everyday life and in the future of millions of people.

In this case, the architect connected architectural design with several other professional fields, and took on new responsibilities typically assigned solely to these other professions. He delineated one new domain in architecture and provided rich fodder for discussions of the scope of architecture before eventually developing new specializations within architecture (or even new professions related to it). His bold involvement in social design highlighted the need for professional services of this type, and the need to delegate them to qualified experts and the necessity of discussing the future of such engagements.

From a broader perspective, the architect positioned himself as a social designer in that he took on responsibilities that should have been taken on by social designers-sociologists, anthropologists, psychologists, organizational/management consultants, or a number of other social professions. By managing the functional planning of the Fun Palace, Price demonstrated the role of the architect as a social leader and innovator in times of rapid sociocultural change. He filled a niche that was starkly vacant and badly needed. The extent of his engagement with social design prompts a rethinking of the division of labor and the professional organization of the project delivery process, and redrawing of ethical responsibilities.

The concept of architect as social designer should generate discussion among professionals from many fields. As a research topic, it deserves to be assessed from numerous aspects. It is imperative that the solution area be preserved broadly and inclusively, making room for deliberations of any kind and allowing for exploring a number of perspectives and options. Presently, it is too early to decide whether architects should become social designers, or whether a new profession should be created to accept these responsibilities. Perhaps the solution is somewhere between. Regardless, this debate should involve a number of related issues-the definition and future of the architectural profession, division of labor in society, professionalization of various activities that until now have been almost intangible, facility delivery practices, and project management. In all cases, architecture can extend a provocation to contemporary society about designing everything, from buildings and cities to educational experiences and new cultures.

\section{REFERENCES}

Allford, David. "The Creative Iconoclast." Cedric Price: Works II. London: Architectural Association, 1984. Print.

Blumer, Herbert. Symbolic Interactionism: Perspective and Method. Englewood Cliffs, NJ: Prentice-Hall, 1969. Print.

Boguslaw, R. The Design Perspective in Sociology. The Sociology of the Future. Ed. Wendell Bell and James Mau. New York: Russell Sage Foundation, 1971. 240-258. Print.
Burrage, Michael, and Rolf, Torstendahl, eds. Professions in Theory and History: Rethinking the Study of the Professions. Thousand Oaks, CA: SAGE, 1990. Print.

Buur, Jacob, Thomas Binder, and Eva Brandt. "Taking Video beyond 'Hard Data' in User Centered Design." PDC 2000: Proceedings of the Participatory Design Conference. Ed T. Cherkasky, J. Greenbaum, P. Mambrey, J.K. Pors. New York, NY, 2000. 21-29. Print.

Callon, Marc. "Some Elements of a Sociology of Translation." Power, Action and Belief Ed. John Law. London: Routledge, 1986. 196-223. Print.

Crinson, Mark, and Jules Lubbock. Architecture-Art or Profession?: Three Hundred Years of Architectural Education in Britain. Manchester, UK; New York: Manchester University Press, 1994. Print.

Cuff, Dana, and John Wriedt, eds. Architecture From the Outside In: Selected Essays by Robert Gutman. New York: Princeton Architectural Press, 2010. Print.

Denzin, Norman. Interpretive Interactionism. 2nd ed. Thousand Oaks, CA: Sage Publications, 2001. Print.

Dingwall, Robert. Essays on Professions. Aldershot, England: Ashgate, 2008. Print.

Dingwall, Robert, and Philip Lewis. The Sociology of the Professions: Lawyers, Doctors and Others. New York: St. Martin's Press, 1983. Print. http://dx.doi.org/10.1007/978-1-349-16979-5

Duffy, Francis, and Les Hutton. Architectural Knowledge: The Idea of a Profession. London; New York: E \& FN Spon, 1998. Print.

Eisenhardt, Kathleen, and Melissa Graebner. "Theory Building from Cases: Opportunities and Challenges." Academy of Management Journal 50.1 (2007): 25-32. Print. http://dx.doi.org/10.5465/AMJ.2007.24160888

Flyvbjerg, Bent. "Five Misunderstandings about Case-Study Research." Qualitative Inquiry 12.2 (2006): 219-245. Print. http://dx.doi. org/10.1177/1077800405284363

Frazer, John. "The Cybernetics of Architecture: A Tribute to the Contribution of Gordon Pask." Kybernetes 30.5 (2001): 641-651. Print. http://dx.doi.org/10.1108/03684920110391896

Gamble, Andrew. Britain in Decline: Economic Policy, Political Strategy and the British State. 4th ed. New York, NY: St. Martin's Press, 1994. Print. http://dx.doi.org/10.1007/978-1-349-23620-6

Garfinkel, Harold. Studies in Ethnomethodology. Englewood Cliffs, NJ: Polity Press, 1967. Print.

Glynn, Sean, and Alan Booth. Modern Britain: An Economic and Social History. London and New York: Routledge, 1996. Print. http://dx.doi. org/10.4324/9780203299609

Holdsworth, Nadine. Joan Littlewood. London and New York: Routledge, 2006. Print. http://dx.doi.org/10.4324/9780203448489

Holdsworth, Nadine. Joan Littlewood's Theatre. Cambridge: Cambridge University Press, 2011. Print.

Iles, Anthony. "Legislating for Enthusiasm: From Fun Palace to Creative Prison." 2009. Accessed July 25, 2014 from http://www.arcade-project. com/sacrifice/Legislating\%20for\%20Enthusiasm.pdf 
Kostof, Spiro, ed. The Architect: Chapters in the History of the Profession. Berkeley, CA: University of California Press, 2000 . Print.

Latour, Bruno. Science in Action: How to Follow Scientists and Engineers through Society. Cambridge, MA: Harvard University Press, 1987.

Littlewood, Joan. Joan's Book: The Autobiography of Joan Littlewood. London: Methuen, 2003. Print.

Lobsinger, Mary Lou. "Cedric Price: An Architecture of the Performance." Daidalos 74 (2000a): 22-29. Print.

Lobsinger, Mary Lou. "Cybernetic Theory and the Architecture of Performance." In Anxious Modernism. Ed. Sarah Williams Goldhagen and Réjean Legault, 119-139. Montreal and Cambridge, MA: Canadian Centre for Architecture and Massachusetts Institute of Technology, 2000b. Print.

Lopes, Gonçalo Miguel Furtado Cardoso. "Gordon Pask: Exchanges Between Cybernetics and Architecture and the Envisioning of the IE." Kybernetes 38.7/8 (2009): 1317-1331. Print. http://dx.doi. org/10.1108/03684920910976998

Luff, Paul, Jon Hindmarsh, and Christian Heath. Workplace Studies: Recovering Work Practice and Informing System Design. Cambridge, UK: Cambridge University Press, 2000. Print. http://dx.doi.org/10.1017/ CBO9780511628122

Macdonald, Keith. The Sociology of the Professions. Thousand Oaks, CA: SAGE, 1995. Print.

Mathews, Stanley. "Cedric John Price (1934-2003)". Architecture and Urbanism 10.397 (2003): 6. Print.

Mathews, Stanley. "The Fun Palace: Cedric Price's Experiment in Architecture and Technology." Technoetic Arts 3.2 (2005): 73-91. Print. http://dx.doi.org/10.1386/tear.3.2.73/1

Mathews, Stanley. From Agit-Prop to Free Space: The Architecture of Cedric Price. London: Black Dog Publishing, 2007a. Print.

Mathews, Stanley. "Cedric Price as Anti-Architect." In Architecture and Authorship. Ed. Tim Anstey, Katja Grillner and Rolf Hughes. London: Black Dog Publishing, 2007b. 142-147. Print.

Nicol, David, and Simon Pilling, eds. Changing Architectural Education: Towards a New Professionalism. London; New York: E \& FN Spon, 2000. Print.

Piotrowski, Andrzei, and Julia Robinson, eds. The Discipline of Architecture. Minneapolis, MN: University of Minnesota Press, 2001. Print.

Price, Cedric. "A Laboratory of Fun.” New Scientist, 22 (1964): 433. Print.

Price, Cedric. Cedric Price, Works II. London: Architectural Association, 1984. Print.

Price, Cedric, and Joan Littlewood. The Fun Palace. The Drama Review: TDR, Architecture/Environment, 12.3 (1968): 27-134. Print.
Rawls, Anne Warfield. "Harold Garfinkel, Ethnomethodology and Workplace Studies." Organization Studies, 29.5. (2008): 701-732. Print. http://dx.doi.org/10.1177/0170840608088768

Sacks, Harvey, Emanuel A. Schegloff, and Gail Jefferson. "A Simplest Systematics for the Organization of Turn-Taking for Conversation." Language 50.4 (1974): 696-735. Print. http://dx.doi.org/10.1353/ lan.1974.0010

Seawright, Jason, and John Gerring. "Case Selection Techniques in Case Study Research: A Menu of Qualitative and Quantitative Options." Political Research Quarterly 61.2 (2008): 294-308. Print. http://dx.doi. org/10.1177/1065912907313077

Shubert, Howard. “Cedric Price: Fun Palace.” Domus 866 (2004): 17. Print.

Silver, Nathan. The Making of Beaubourg: A Building Biography of the Centre Pompidou, Paris. Cambridge, MA: MIT Press, 1994. Print.

Smith, Ronald W., and Valerie Bugni. "Symbolic Interaction Theory and Architecture." Symbolic Interaction 29.2 (2006): 123-155. Print. http:// dx.doi.org/10.1525/si.2006.29.2.123

Stevens, Garry. The Favored Circle. Cambridge, MA: The MIT Press, 1998. Print.

Torstendahl, Rolf, and Michael Burrage, eds. The Formation of Professions: Knowledge, State and Strategy. Thousand Oaks, CA: SAGE, 1990. Print.

Whalen, Jack, and Erik Vinkhuyzen "Expert Systems in (Inter)action: Diagnosing Document Machine Problems over the Telephone." Workplace Studies: Recovering Work Practice and Information System Design. Ed. Paul Luff, Jon Hindmarsh, and Christian Heath. Cambridge, UK: Cambridge University Press, 2001. 92-140. Print.

Whalen, Jack, and Marilyn Whalen. "Integrated Customer Service: Reinventing a Workscape." Making Work Visible: Ethnographically Grounded Case Studies of Work Practice. Ed. Margaret Syzmanski and Jack Whalen. Cambridge, UK: Cambridge University Press, 2011. 181204. Print. http://dx.doi.org/10.1017/CBO9780511921360.013

Wigley, Mark. "Anti-Buildings and Anti-Architects." Domus 866 (2004): 15-16, 22. Print.

Wilken, Rowan. "Calculated Uncertainty: Computers, Chance Encounters, and 'Community' in the Work of Cedric Price." Transformations 14 (2007). Accessed August 10, 2014, from http://transformations.cqu.edu. au/journal/issue_14/article_04.shtml

Woods, Mary. From Craft to Profession: The Practice of Architecture in Nineteenth-Century America. Berkeley, CA: University of California Press, 1999. Print. 